\title{
SYUHADA MOSQUE AND ITS COMMUNITY IN CHANGING YOGYAKARTA, I95OS-I98OS
}

\author{
MUHAMMAD YUANDA ZARA ${ }^{1}$
}

\begin{abstract}
One of Yogyakarta city's symbols of colonialism is the Kotabaru region, which during the colonial period was a housing complex for Dutch officials and a handful of Indonesian elite. The Japanese took over the area during their Occupation. Following Indonesian independence, Indonesians seized the area for the interests of the newly born Republic of Indonesia. Syuhada Mosque, the first modern mosque in post-independence Indonesia, was then built there, representing both Islam and Indonesian nationalism, as the mosque's name and location suggest. Unlike most Indonesian mosques at the time, which were established primarily as a place for worship, Syuhada brought social and political missions. The activities of its community encompassed religious practices (such as five obligatory daily prayers and recital of Koranic verses), handling social matters (education for children, youth and women, debate on Islam and modernity, and counter-Christianization activities), as well as responding to national politics (such as the anti-Communist movement in I96os). Its community mostly lived outside the immediate environment of the mosque, yet Syuhada managed to present itself not just as a mosque for a small community, but for a city, even for the Indonesian nation-state. Given its four decades of overarching religious and sociopolitical functions, the mosque is deliberately aimed at a new generation of Indonesian Muslims: middle class, urban, educated, and open-minded Muslims, and serves as a role model for later mosques and religious institutions.
\end{abstract}

Keywords: Syuhada Mosque, Islam, nationalism, Muslim community, Yogyakarta, decolonization in Indonesia, modernity

\begin{abstract}
Abstrak
Salah satu simbol kolonialisme di Yogyakarta adalah kawasan Kotabaru, yang selama masa kolonial dikenal sebagai kompleks pemukiman pejabat Belanda dan beberapa orang Indonesia dari kalangan elite. Jepang mengambil alih kawasan ini di masa pendudukannya. Setelah Indonesia merdeka, kawasan ini dikuasai orang Indonesia dan digunakan untuk kepentingan negara Republik Indonesia yang baru lahir. Masjid Syuhada, masjid modern pertama sesudah Indonesia merdeka, didirikan di sana, dan mencerminkan baik Islam dan nasionalisme Indonesia, sebagaimana ditunjukkan oleh nama dan lokasi masjid tersebut. Berbeda dengan sebagian besar masjid di Indonesia pada saat itu yang umumnya dibangun hanya sebagai tempat ibadah, Syuhada mempunyai misi sosial dan politik. Aktivitas komunitasnya mencakup praktek keagamaan (seperti shalat lima waktu dan pengajian), menangani masalah sosial (pendidikan anak, pemuda/i, dan wanita, debat soal Islam dan modernitas, dan oposisi terhadap Kristenisasi), dan merespon situasi politik nasional (seperti gerakan anti-komunis tahun I96oan). Meski komunitasnya terutama berasal dari luar lingkungan terdekatnya, namun Syuhada berhasil menampilkan dirinya tak hanya sebagai sebuah masjid untuk suatu komunitas kecil, melainkan untuk sebuah kota bahkan negara. Mengingat empat dekade fungsi keagamaan dan sosiopolitiknya, masjid ini memperlihatkan posisinya sebagai masjid yang ditujukan kepada sebuah generasi baru Muslim Indonesia: Muslim kelas menengah, urban, berpendidikan dan berpikiran terbuka, dan berperan penting sebagai teladan bagi masjid dan institusi keagamaan yang muncul di kemudian hari.
\end{abstract}

Kata kunci: Masjid Syuhada, Islam, nasionalisme, komunitas Muslim, Yogyakarta, dekolonisasi di Indonesia, modernitas

I Obtained PhD at Amsterdam Institute for Social Science Research (AISSR), University of Amsterdam, Amsterdam Roeterseilandcampus, Nieuwe Achtergracht I66, I0I8 WV Amsterdam. Email: myuzara@gmail.com.

This study is largely based on my undergraduate thesis at History Department of Gadjah Mada University. I have revised it based on some new sources and analyses. I thank to my supervisor, Prof. Bambang Purwanto, who helped me to formulate a number of essential aspects in examining the connection between a place for worship, its community and a changing urban space.

Copyright (20I6 The Author, (20I6 Deputy of Social Sciences and Humanities. All rights reserved. Printed in Indonesia. Journal of Indonesian Social Sciences and Humanities (JISSH); Vol. 6, Issue 2, (2016), Pp. 13-28. ISSN: I979-843I. 


\section{INTRODUCTION}

There is a strong tie between religion, the religious community, the environment and the building (Supardi \& Amiruddin, 200r: I2). Islam is no exception. In Islam, a masjid (mosque) is principally used for conducting one of the most important elements in Islam: Muslim prayer (shalah). Yet, throughout Islamic history, it is evident that a mosque is not solely utilized for that, but it is also used for dealing with sociopolitical matters that exist within its religious community. In the time of the Prophet Muhammad, for instance, a mosque was used as a place of worship,for a meeting room, a safety room, a curing room for the sick, as well as a place to arrange war strategy, teaching and proselytizing (Yani, I999: 13-23).

Nevertheless, most studies concerning mosques in the Islamic world pay too much attention to the physical elements of a mosque, or to be precise, on the achitectural forms and artistic styles of mosques in different parts of the Islamic world; ranging from the Arab world (Creswell, I934; King, I978), Palestine (Rosen-Ayalon, 2006), North Africa (Al-Asad, I992), Turkey (Yetkin, I959; Al-Asad, I999; As, 2006), the Indian subcontinent (Parihar, 2004), and Southeast Asia (Bruce, I996). Studies on mosques in Indonesia reflect this trend, including De Graaf (1963), who traces the architectural history of Javanese mosques until the I4th century, Pamungkas (I996) details the renovation of the Great Mosque of Yogyakarta under Sultan Hamengku Buwono VIII. Kusno (2003), examines Indonesian mosques' architecture as a contested space among traditional Islam rooted in Indonesian society, transnational Islam especially from the Middle East, and the Indonesian state as represented by Suharto's New Order. In other words, mosques have primarily been seen as a (historical) monuments whose artistic styles have changed over time, meaning that each mosque is a site to inspect the prevailing architectural design and a ruling regime that built the mosque in a specific region at a given time. Therefore, mosque studies mainly concentrate on mosque structures such as the dome, minaret, porch, roof style, mosaics, mihrabs, walls, decorations, and inscriptions.
As a consequence, scholars largely overlook the sociopolitical roles that mosques play in different localities. Only very minor studies have been carried out on how a mosque reflects not just a specific architectural history, but also its relations with the society that builds and uses it. These include a study about the role of a mosque as an educational institution during the early middle ages (Imamuddin, I984), on a mosque's role in providing social and moral supports for Muslim youths in the United States (Nguyen, et. al., 2013) and on the use of the Jogokariyan Mosque in Yogyakarta as a public sphere where the mosque was opened for various social and educational functions (Prasetya, 20I4).

To the best of my knowledge, this research is a pioneering study which examines the little known, but undoubtedly important, issue of the position of a mosque and the dynamics of its religious community in a changing society, city and state in an Indonesian context. This study will shed new light into how Indonesian Muslims use mosques for different sociopolitical goals (so, not just for praying) over several decades in post-independence Indonesia. These decades, especially from the I950s to the I980s, were largely marked by the decolonization of Indonesia, the rise of the Indonesian nationstate, the contest for power between military and civilian leaders, the birth of an Indonesian Muslim middle class, and Muslims' rivalry with other world religions, especially Christianity.

This study focuses on Syuhada Mosque located in an Islamic enclave of Yogyakarta, Indonesia. This mosque was deemed to be the most modern mosque in Indonesia in the I950s, long before the bigger and more well-known mosque, which also carried a sense of decolonization, the Istiqlal Mosque (Independence Mosque) in Jakarta, was built (officially opened in 1978). Compared to other mosques of its time, Syuhada's distinctive features included its modern facilities and its prominent roles in sociopolitical changes occuring in Yogyakarta and Indonesia from the I950s until the I980s. This research examines Syuhada Mosque not from an architectural point of view, but from a social history perspective of its urban Muslim community and management. I will 
answer the following questions: I) How was the Syuhada Mosque built in the context of Dutch colonialism, Japanese Occupation, and the Indonesian revolution? 2) How did Syuhada Mosque's management and community respond to sociopolitcal changes taking place around them, both in a local and national context? 3) How has Syuhada Mosque represented a modern Islam in Indonesia? By using historical method and examining written documents as well as interviews with those associated with the mosque, this study explores Syuhada from its establishment in the I950s to its peak of activities in theI980s.

\section{THE ORIGIN OF KOTABARU}

Historian Fakih (2005) drew the historical roots of Kotabaru to the last quarter of twentieth century, especially when in I870 the Dutch colonial government applied Agrarische Wet, which allowed the entry of foreign capital into the Dutch East Indies. One of the implications were the increasing number of Europeans, mainly Dutch, who came to the colony. The Europeans were given freedom to design and implement their plans with regards to their life among the natives. In Yogyakarta, Central Java, the existing European housing complex of Loji Kecil was no longer sufficient to house these new Europeans, a place named Kotabaru was becoming the new alternative for housing.

Located east of the Code River, a main river of Yogyakarta whose water originates from Mount Merapi (9,6ro ft), Kotabaru was geographically beneficial for Europeans looking for a new housing complex. Kotabaru was very close to Tugu Station, Yogyakarta's main train station that was opened in 1887 and connected the city with Java's other cities (Hudiyanto, I997). Kotabaru's design was radial, emulating Dutch cities and contrasting to the native kampungs. Other characteristics of Kotabaru included big trees, wide main roads, and the presence of various modern public facilities (Utomo: 2007; Fakih: 2005). Soon after it was opened, Kotabaru was inhabited by Whites along with a few Dutch-educated Indonesians (Suratmin: 200I, II). In I920, Kotabaru became the most concentrated European housing complex in Yogyakarta (Hudiyanto: 1997: 63).
The Dutch capitulation to the Japanese in I942 caused major changes in the East Indies, including Yogyakarta. After the sudden flight of the Dutch inhabitants, Kotabaru was reopened. Similar to the Dutch, the Japanese occupying forces used Kotabaru as their housing and governance complex, including offices, military barracks, warehouses, etcetera (Kurniawati dan Nurhajarini, 2005).

Indonesian independencewas proclaimed in Jakarta by Sukarno on I7 August, I945 and received a warm welcome in Yogyakarta. The Sri Sultan Hamengku Buwono IX of Yogyakarta Sultanate congratulated the new Republic and asserted his support behind it. Government offices and private houses, which were previously occupied by the Japanese, were taken over by Indonesians despite Japanese resistance.

Pro-Republic elements in Yogyakarta, inter alia the armed youth, demanded the Japanese leave Yogyakarta, including abandoning Kotabaru. The Japanese refused, and a battle between Japanese troops and armed Indonesians ensued on 6 and 7 October, 1945 (Suwarno: 1994, 179). A number of victims fell from both sides while Kotabaru was finally taken over by pro-Republic supporters (Harnoko, et. al.: 2003, I9).

This Indonesian victory over the Japanese shortly after the Pacific War had ended was one of the starting points of decolonization in Indonesia. Generally, post-independence decolonization refers to efforts to remove any colonial identity and replace it with a new identity in order to reflect Indonesianness (Kurniawati \& Nurhajarini, 2005: 6-7). Practically, that means the production of new symbols by changing existing urban identities and the function of urban spaces, to make a completely new identity.

In Kotabaru, such image change was started by the act of pro-Republic supporters in Yogyakarta to preserve the story of Indonesian nationalism by using the names of Indonesian victims of the battle of Kotabaru as the names of Kotabaru's streets. Moreover, the abandoned houses were subsequently filled by Indonesians, including Indonesian Muslims, who would later became a significant factor in the establishment of Syuhada Mosque (Suratmin, 200r: 
II). The process of Indonesicizing Kotabaru rapidly continued when the Indonesan capital was moved from Jakarta to Yogyakarta in early I946. A number of buildings in Kotabaru were utilized for the Republic's interests, including as government offices and houses for Republican officials (Kurniawati dan Nurhajarini, 2005, 25). In short, Kotabaru was now becoming a symbol of Republican triumph over Dutch colonialism and Japanese Occupation.

\section{SYUHADA MOSQUE: IDEA AND IMPLEMENTATION}

Through the Round Table Conference, on 27 December, 1949, the Dutch transferred sovereignty to the Republic of the United States of Indonesia, in which the Republic of Indonesia was one of its parts. As a consequence, the Republic of Indonesia's capital was returned to Jakarta. Before leaving Yogyakarta, a number of central Republican leaders held a talk with nationalist and Muslim leaders of Yogyakarta. This meeting consisted of three parties with considerable sociopolitical power at that time: the Yogyakarta Sultanate (represented by Sri Sultan Hamengku Buwono IX and GBPH Prabuningrat), the central Republican government (represented by Assaat and Prawoto Mangunkusumo) and Islamic leaders (represented by Haji Benjamin, Haji M.J. Prawirojuwono, Jatim Mansjur, Abdul Madjid and Kahar Muzakkir).

They all agreed that Yogyakarta greatly contributed to the independence struggle and national revolution to maintain Indonesian independence (Suratmin, 200I, I7). Therefore, before leaving Yogyakarta for Jakarta, it was expected that a souvenir was left in Yogyakarta, a souvenir that should strongly reflect the resistance against colonialism. They decided to choose a mosque for several reasons. Firstly, as a city populous with Muslims, Yogyakarta only had two major mosques, Kauman Great Mosque and Pura Pakualaman Mosque. Secondly, most of Kotabaru inhabitants were now Muslims, and they were in need of a proper place to carry out prayer together, especially Friday prayer. They usually performed Friday prayer at houses, grass fields or even borrowing a room from the nearby Protestant church (Kenang2an, I952: I8-I9).
A committee, led by the former Acting President of the Republic of Indonesia, Assaattwo previous committees had failed for various reasons-was formed to establish the mosque. Assaat organized a group which adopted a rational and professional organization of the construction process reflective of the Dutch era. Some new members joined the committee, including Lieutenant Colonel Suharto, Commander of Diponegoro Division of Central Java (later becoming Indonesian president) (Suratmin, 200I: 26; Kenangzan, I952: 6). This meant that the Army became a significant part of the establishment of the mosque. Meanwhile, the advisory board was led by the minister of religious affairs (Keterlibatan Ulama, 2000).

But what about the name of the mosque? After a series of discussions, one committee member, Haji Benjamin, proposed 'Masjid Syuhada' or Syuhada Mosque, which was soon approved by the rest of the committee members. The location for the mosque was settled in consultation with the Sultan whilst the mosque was designed by R. Feenstra, a well-known architect from Jakarta. Financial support for the mosque was collectively provided by the Sultanate, central government, generous contributors, and the public at large.

The mosque was built within two years and was officially opened on 20 September, I952. Those attending the opening ceremony represented local and national political powers, indicating the importance of the mosque and the significance behind it. They were, among others, President Soekarno, a few of his ministers, Paku Alam VIIl, Major of Yogyakarta S. Poerwokoesoemo, Governor of Central Java Budiono, Commander of Diponegoro Division Col. Moch. Bachrun, and Major of Solo Muhammad Saleh. Syuhada Mosque was therefore the first mosque to be formally launched by local and national politicians in post-independence Indonesia, thus reflecting a relative unity of Indonesian leaders in commemorating the end of Dutch and Japanese occupation through the combined symbols of Indonesia ('syuhada' or martyr) and Islam (a mosque) in a previously exclusive white enclave that symbolized colonalism. 


\section{INNOVATIONS AT SYUHADA MOSQUE}

Compared to other mosques in Indonesia in the I950s, the Syuhada Mosque was perhaps the most modern in terms of facilities. In addition to a partition of prayer halls between men and women, a special room was allocated for women on the ground floor as a changing/ makeup room. This was a breakthrough, given that the majority of Muslims saw the mosque as a male territory,interpeting one of the Prophet Muhammad's words which state that women are better performing prayer at home. Syuhada, therefore, asserted that it welcomed women and recognized one of women's major needs: makeup. Indeed, it was partly for this reason that some Muslim women came to Syuhada. Meanwhile, the toilet and bathroom were made of good quality materials and were carefully maintained. Sandals were no longer spread in the frontyard, but were put on racks (Suratmin, 2001: 49). There was also a hall which was used as a lecture room; at that time, Syuhada Mosque was famous because of this room (Mesjid-mesjid Bersejarah, n.d.: Io). Of no less importance, Syuhada had a library. Other facilities were a loud speaker and a telephone. A small studio was built inside the mosque, through which sermons were broadcast by radio all over the city (Masyhuri, personal communication, January I2, 2007). The mosque also had an electronic device to record the sermons (Suratmin, 200I: 38). When it was officially opened, Syuhada's floor was covered by a beautiful and expensive carpet, which was donated by the Pakistani Embassy in Jakarta (Kenang2an, I952: 30).

The Syuhada Mosque added to the number of jami' (grand) mosques in Yogyakarta. The Kauman and Pakualaman Mosques symbolized the Sultanate's acceptance of Islam amidst Javanese culture. They were both deemed special because of their historical and cultural values. However, Syuhada was given considerable attention mostly because of its emphasis on modernity, rather than traditionality. Muqaddimah, one of my sources, stated that the mosque:

The most modern. The biggest one. So many people came to see it once it was officially opened. Some came just to watch it. Muslims were especially proud to have such mosque (Muqaddimah, personal interview, February I4, 2007).

In order to attract more Muslims, Syuhada Mosque used the most modern communication media available at that time: radio. (Muqaddimah, personal interview, February I4, 2007). There was a small room behind the mihrab where a device was placed to broadcast the sermons via Radio Republik Indonesia (RRI) (Suratmin, 200I: 49; Masyhuri, personal communicayion, January I2, 2007).

Taking the process of modernization of Islam in Indonesia into consideration, the use of radio was a breakthrough. It cut through the distrust held by some Muslims (during the colonial era) to elements of modernity, such as the use of horn (loud speaker) and Western-style clothing like trousers and suits by Islamic teachers. In other words, the use of radio for proselytizing Islam shows that the process of Islamic modernization continued and even thrived.

\section{A CONVENIENT AND COMPLETE MOSQUE}

According to historian Kuntowijoyo, a mosque is similar to a bus station. Once a person comes to the station, he considers that he has reached his aim. Kuntowijoyo equates this with a Muslim going to a mosque. A Muslim usually comes there to pray, sit for a moment, and then returns home, without ever talking to, let alone getting to know, those sitting next to him (Kuntowijoyo, I994: I32).

Kuntowijoyo, therefore, criticizes Muslims who see the mosque as only a place for worship. Syuhada Mosque was completely different from this general picture of mosques in the Islamic world. A few years before the establishment of Syuhada, a group from the muslim community was present in Kotabaru. This group later became the pioneers of Islamic activities at Syuhada. Around I943, some women in Kotabaru created a womens club (arisan) and formed a Koran recital group named the Association of Koran Recital for Women (Perhimpunan Pengajian Puteri Kotabaru, PPPK) (Suratmin, 200I: 78). 
In its early years, its members reached 400, consisting not just of those living in Kotabaru, but also from other parts of Yogyakarta. The members from other parts of Yogyakarta were expected to, after getting knowledge and experience from the PPPK, initiate their own recital groups in their area (Suratmin, 200I: 78). The activities of the PPPK soon broadened and included education and financial matters. Its name was then changed into the Women's Koran Recital of Yogyakarta (Pengajian Puteri Yogyakarta, PPY). PPY members were active in collecting money during the foundation of Syuhada (Suratmin, 200I: 79). Once Syuhada was in operation, PPY members asked for a special room for women. This proposal was accepted. Subsequently, the activities of PPY expanded into recital groups for children and girls and such activities as money saving, a library and other social matters. These activities were so popular that many women throughout Yogyakarta participated in them.

It should be noted that, unlike most Indonesian mosques, whose earliest religious activities were almost always fully organized by men and primus inter pares, the seeds of religious efforts in Syuhada were initiated by women. These women played an important role in creating the basis for the subsequent activities once Syuhada was ready to use.

In addition to Koran recital for women, another striking program of Syuhada in its formative years was a great emphasis on children's education. A new generation of Muslims was being prepared to replace their parents as a part of the Syuhada community of the future, as well as making them ready as new cadres for Islamic proselytizing. Practically speaking, children were nominally one of the largest groups that came to the Mosque (Muqaddimah, personal communication, February I4, 2007). Usually they were taken there by their mothers who came for Koran recital. From here, an awareness grew among the mothers to provide religous education for their children.

Therefore, on 20 October, I953, under the Foundation for Dormitory and Mosque (Yayasan Asrama dan Masjid, YASMA) as the umbrella organization, an eduational institution was established and named Children Education's of Syuhada Mosque (Pendidikan Anak-Anak Masjid Syuhada, PAMS) (Suratmin, 200I). In addition to providing religious education to children, the aim of the PAMS was to attract children's enthusiasm to come to the mosque. Given these goals, the education for children was concentrated on Syuhada Mosque. Every afternoon, or after school hours, children, who mostly lived in Kotabaru, came to the mosque (Muqaddimah, personal communication, February I4, 2007).

According to an interviewee, at that time Syuhada was the only mosque in Yogakarta which offered an education program for children, now widely known as Taman Pendidikan Al-Qur'an (Koranic Kindergaten, TPA) (R. Lubis, personal communication, February 2I, 2007). The children participating in it originated both from Kotabaru and outside. They were taught, inter alia, reading Koran and performing prayer. The curriculum resembled that of the Department of Religious Affairs.

After several years, the children's education program improved and encouraged Syuhada management to create a more comprehensive and well-planned school for kids. That meant teaching a combination of religious studies and general knowledge. The management opted to establish a kindergaten, Taman Kanak-Kanak (TK) Masjid Syuhada (Syuhada Kindergarten), which opened on I6 August, I960 (Suratmin, 200I; 67). This enhanced the image of Syuhada as a mosque for modern Muslims, a mosque that prepared young Muslims to not just become knowledgeable in religious matters but also in skills that would allow them to enter the larger world that was often characterized by systematic knowledge, science, and professionalism rather than piety. Now Syuhada was no longer only focussed on religious practices, but was also a playground for children. One of the graduates of the TK Syuhada was Anies Baswedan, former minister of the Ministry of Education and Culture of Indonesia (Husnil, 20I4: I3).

The number of enrollments to the TK Syuhada grew annually. Management, curriculum, teachers, and facilities were all improved. 
The TK soon became a trendsetter, not just in Yogyakarta, but also across Indonesia. This TK, for instance, was an example for later modern Islamic TK, such as the famous TK Al Azhar in the national capital, Jakarta (Muqaddimah, personal communication, February I4, 2007).

During Ramadhan (fasting month), students who stayed at the male dormitory, in cooperation with Syuhada management and the Syuhada community, held a number of events to celebrate it. Tarawih prayers at night during Ramadhan and Koran recital were the two main ritual practices. Unlike the majority of Indonesian mosques at that time who presented an Islamic teacher as the preacher before Tarawih, it was not uncommon for Syuhada to allow graduates from secular universities to deliver religious sermons from the podium. Indeed, this sort of speaker soon became one of the most important drawcards that attracted people to come and pray at Syuhada (A.A. Darban, personal communication, September I7, 2007). This trend continued to grow, and played a role in making Syuhada a mosque not just for devout Muslims, but also for intellectual and rational Muslims.

\section{ISLAM AS IDEOLOGY, MOVEMENT, AND IMAGE}

In the beginning, Syuhada Mosque's activities mainly focused on maintaining and improving the religious devotion of its community. Later, Syuhada began to assume a new role, namely as an agent of social change at the city and national level. Below I will explain various sociopolitical changes in Yogakarta and Indonesia from I960s onwards, their influences on Syuhada, and how Syuhada responded to them. These include the changing composition of the inhabitants of Kotabaru, the strengthening of the the socalled politik aliran (division of political groups based on ideology, religion, and social lines), which was partly marked by NU's decision to leave Masyumi Party, thus sustaining friction between traditionalist muslims represented by NU and modernist muslims represented by Muhammadiyah, the rise of the Indonesian Communist Party (Partai Komunis Indonesia, $\mathrm{PKI}$ ) and its youth wings, christianization, and the rise of young, Indonesian muslim intellectuals educated on secular campuses rather than in religious schools.

Sociologically speaking, since the early I970s, there was a major change in the composition of the inhabitants of Kotabaru. Some of the government officials who lived there since the revolution era passed away. The houses were inherited by their children (Masyhuri, personal communication, January I2, 2007). Unlike their parents, this new generation was not very active in Syuhada and some of them sold their parents' houses, which were then used for office or business facilities. Thus, the function of Kotabaru as a public settlement decreased.

This situation definitely influenced the composition of the religious community of Syuhada. The mosque lost many of its main supporters in Kotabaru, which was a critical issue for both the short and long term. In dealing with this, a number of efforts were conducted to attract these new inhabitants to the mosque. Representatives of Syuhada frequently sent invitations for every event that was going to be held to them. Yet, even though most of them were Muslims, they showed little interest in participating in mosque-held activities.

Afterwards, the mosque targeted a broader audience, namely wider Yogyakarta, especially the newly rising Indonesian muslim middle class, which at that time was emerging as a major part within Indonesian Muslimsociety. By the late i960s a new generation of Muslims appeared with a modern education, which soon formed the Indonesian middle class. In Indonesian social sciences, they were labeled santri-priyayi (Mahasin in Tanter and Young [eds.], I993: 153-4). In the Syuhada context, they were university students, lecturers, bureaucrats and young Muslim entrepreneurs whose numbers steadily increased. Their great attention to Islam, both the more superficial aspects of Islam and the more stricter application of Islamic principles broke the myth that their occupations were far from Islam.

According to Latif (2012: 583), the I970s was the period of 'Islamic turn'.This took place in many of Indonesia's secular unversities, largely marked by the proliferation of remaja 
masjid (youth mosque groups) and was directed mainly by student activists with an HMI (Islamic Student Association)/PIl (Indonesian Muslim Students) background. Students' dissatisfaction in regards to restrictions on publicly expressing political aspirations were channeled through the so-called 'Back to the Mosque' movement. Syuhada Mosque was among the mosques in Indonesia's major cities, along with $\mathrm{Al}$ Azhar (Jakarta), Istiqomah (Bandung), and Al Falah (Surabaya), whose remaja masjid were very active in proselytizing Islam through methods and programs borrowed from Islamic movements in the campus mosques.

Later, there was another 'turn' in the dakwah movement in the Syuhada Mosque, which was introduced by national-level Islamic activists in Syuhada. Sopyan (20I4:32) mentions two influential names: Habib Chirzin, an activist closely linked with numerous Islamic student organizations such as HMI, PII, IMM, and Jamaah Shalahuddin, and Chumaidy Syarif Romas, chair of HMI (1976-78). They gradually modified Syuhada's main dakwah method from bil lisaan (through verbal communication) into bil haal (enabling Muslim preachers to help solve actual problems faced by the Islamic community), or what was later known as dakwah transformatif (transformative proselytizing). Chirzin believed that Syuhada's dakwah was too normative, that it faced difficulties in keeping pace with the modern world and introduced the use of social science methods in solving the problems of the Muslim society (Sopyan, 20I4: 79).

One of the backbones of Syuhada's dakwah activities was Cadre Training of Syuhada Mosque (Pendidikan Kader Masjid Syuhada, PKMS), established soon after the opening of the mosque. Those youths trained in this organization were expected to be good preachers, who were not just able to effectively disseminate religious messages, but also to connect with the needy population. In order to bridge the gap between such spiritual and concrete tasks, the PKMS recruited university students from different academic backgrounds as its teachers, especially from Gadjah Mada University (UGM), State Institute of Islamic Studies (Institut
Agama Islam Negeri, IAIN) Sunan Kalijaga and Islamic University of Indonesia (Universitas Islam Indonesia, UII). Most of the students who took part in PKMS' cadre training were senior high school students in Yogyakarta (Sopyan, 20I4: 7I).

Interestingly, the image of Syuhada did not just draw people to come, pray or enroll their children in Syuhada's schools, but also gave rise to a new way to celebrate its respected position among Muslim communities in Yogyakarta. This came in a form that the founders of Syuhada would not have imagined. In the I970s, as a sign of the popularity of Syuhada in Central Java: the picture of Syuhada Mosque was used as a backdrop in photo studios. There were only two mosques that were commonly used as backdrops in photo studios at that time in the region: Syuhada and Kauman Mosque. In Eid al-Fitr or Lebaran, Muslim families in the region gathered themselves, and in order to celebrate the joyful day and as a memory of the family gathering, they went to a photo studio for a picture. Strassler (2010: 93) stated that these backdrops 'depicted particular mosques that were as much symbols of locality as they were signs of religious identity.' However, after I980s, Strassler continues, photo backdrops in studios in Central Java preferred mosques with archictetural styles that resembled to that of South Asia and the Middle East, reflecting Indonesian Muslims' growing association with larger Islamic world.

\section{SYUHADA, NU AND MUHAMMADIYAH}

Differences in understanding the secondary principles of Islam (khilafiyah) split Indonesian muslims into two groups, modernists and traditionalists. The former was represented by Muhammadiyah and the latter was represented by Nahdlatul Ulama (NU) (Noer, I973). It is therefore relevant to relate the establishment of Syuhada with such dualism. The question is: On which side did Syuhada stand? Posing this question to a member of the YAMSA management, B. Mukri, he replied that Syuhada was 'neutral' (B. Mukri, personal communication, February 20, 2007). Meanwhile, the grand imam 
of Syuhada, Masyhuri, acknowledged that when Syuhada was used as a place for worship, the community tended to use Muhammadiyah interpretations for khilafiyah matters. This was due to the fact that most of those who were involved in the establishment of the mosque originated from Muhammadiyah, with only a handful of NU representatives (Masyhuri, personal communication, January I2, 2007).

This inclination can be seen during the two prayers that are often under dispute between traditionalist and modern groups: Subuh (early morning prayer) and Tarawih (night time prayer). At Syuhada, in every Subuh prayer the imam did not recite qunut (a prayer recited in the second rakaat of Subuh prayer) while during Tarawih the imam performed II rakaat (motions and prayers in a prayer). These were widely practiced among Muhammadiyah followers. In the NU, however, in every Subuh prayer the imam read qunut and he performs 23 rakaat during Tarawih prayer. But, Syuhada management believed that such matters were not principle ones and were convinced that the Muslims performing prayers at the Syuhada were wise enough to not let the khilafiyah disputes become a major issue.

Ideologically speaking, in terms of new trends and debates in Islamic thought, activists at Syuhada Mosque were quite knowledgeable, yet they tended to avoid taking part in such disputes, let alone adopting a firm stance. One example of this is the notion of the renewal of Islamic thought through secularisation, which was then opposed by many critics, but mushroomed in I970s within Muslim students in Indonesia. Syuhada activists maintained at least two attitudes, namely keeping good relationships with activists from both groups and stressing that Syuhada was open for any development in Islamic thought without limiting or associating itself with a specific school of thought or religious trend (Sopyan, 2014: 79-80).

\section{FROM KULIAH SUBUH TO DAKWAH UNIVERSITY}

In Islam, Subuh prayer occupies a special position. The phrase 'Assholatu khairun minannaum', in Subuh Adhan or call for prayer means 'Prayer is better than sleep'. It reflects the importance of waking up early and starting daily activities with prayer. At Syuhada, the situation regarding Subuh prayer was very complex. In the first years after its official opening, performing Subuh prayer at Syuhada was not an easy task. All parts of Kotabaru were covered by big trees, which were useful for people during the day to provide protection from the harsh sun. But they were a problem during the nightand at dawn. Before Syuhada was built, some parts of Kotabaru were considered unsafe, especially those located next to or around the native kampung of Kali Code.

So, attracting people to Subuh prayer was a challenging job. A strategy was needed. The management of Syuhada held the so-called kuliah subuh (Masyhuri, personal communication, January I2, 2007). This was a short teaching of Islamic principles by using brief and undemanding content. The name of the program itself, 'kuliah' (lit. lecture), represents the aspirations of the management to apply a modern approach to Islamic teaching since the term was more commonly used in secular universities. The teachers of kuliah subuh encompassed Islamic teachers, such as kyai from Krapyak, a well-known Islamic enclave in Yogyakarta, but also university lecturers, confirming the idea of kuliah and showing the close relationship between Syuhada's modern Islam and secular institutions like universities (B. Mukri, personal communication, February 20, 2007; R. Lubis, personal communication, February 2I, 2007).

The presence of popular figures during kuliah subuh impressed many members of Syuhada's religious community. At that time, only Syuhada in Yogyakarta had such a kuliah subuh program (B. Mukri, personal communication, February 20, 2007). Word of the program was extensively spread all over Yogyakarta and drew more people to Syuhada at dawn, both to perform Subuh prayer and to listen to the kuliah subuh. Later, in order to accommodate a broader audience, kuliah subuh teachings were relayed through the state-owned radio, RRI. For Muslims in Yogyakarta living in the mid-I950s, kuliah subuh at Syuhada was very popular. And it can be argued that the kuliah subuh was then 
the icon of Syuhada. This gradually changed and crumbled as Kotabaru's image became increasingly dark and unsafe.

\section{SYUHADA VIS A VIS COMMUNIST}

In the mid-I950s, two national organizations with widespread local branches, the Indonesian Communist Party (Partai Komunis Indonesia, PKI) and Masyumi Party competed for supporters. They both had similar numbers of supporters, and during the first national election in 1955 they managed to reach the big five. The PKI branch in Yogyakarta was very active in agitating the public and one of its most active wings was the Mataram People's University (Universitas Rakyat Mataram, UNRA Mataram) (Suratmin, 200I: 56). Located next to what is now known as Pasar Ngasem, Yogyakarta, this university taught its students communism and prepared them as new communist cadres. Students of the university mainly moved through a student organisation named the Indonesian Student Movement Center (Central Gerakan Mahasiswa Indonesia, CGMI). They often held actions which attracted public attention, in particular a series of mass demonstrations.

The growing influence of the communist university was seen as threat by muslims in Yogyakarta. Indeed, at that time higher education in Yogyakarta, just like at the national level, was divided based on ideology. According to a source, in Yogyakarta, the Islamic university was represented by UII, established in I945, whilst the nationalist university was represented by Janabadra University (Universitas Janabadra, established in I958), and the communist university, as noted above, was represented by UNRA Mataram (Sejarah Universitas Atma Jaya, I990). In order to respond to the spread of communism via various communist-operated media outlets, Syuhada management initially used kuliah subuh to disseminate anti-communist ideas. According to one interviewee, during the early I960s, the Islamic teachers who delivered sermons and teachings at Syuhada were the most 'rigorous' (A.A. Darban, personal communication, September I7, 2007). They mainly provided teachings that strengthened the most fundamental aspects of Islam, which were often seen as the one that differentiated Islam from other ideologies, namely tawhid or the idea about the oneness of God.

When kuliah subuh was deemed insufficient to counter the spread of communism, another idea came into view, namely improving the Islamic teaching program (Suratmin, 200I: 57). A meeting was held among members of Syuhada management and a decision was taken to establish a university. The name of the university, the People's University of Higher Education of Syuhada Mosque (Universitas Rakyat Pendidikan Tinggi Masjid Syuhada, UNRA PTMS), would immediately attract attention and remind people of the university built by the PKI. It was established on ro November, I96I. The choice of this date was not without reasons. Io November was Heroes Day, a nationally commemorated day in Indonesia. Given this, the founders of UNRA PTMS wanted the students educated at the university to follow the path of heroes who fought for Indonesian independence as well as defending the existence of Islam (Suratmin, 200I: 57).

Despite the fact that the university was a higher education institution, the key programs at UNRA PTMS inclined toward ideology rather than the production of knowledge. The university's main aims were to strengthen the basis of Islam among Muslims and to oppose communist propaganda. It is then understandable that a series of requirements of modern higher educational institution such as structure, curriculum and formality were put aside. Accentuation was given to the recruitment of the masses. Normally, when one wants to enroll at a university, he/she needs to have a Senior High School degree. But this did not apply at UNRA PTMS. The most important thing was, according to an interviewee, 'spirit to commit jihad [struggle], to defend Islam' (Masyhuri, personal communication, January I2, 2007).

The founders of the university, Drs. Widjisaksono, Drs. Shalahuddin Sanusi, and Drs. Rusdi Ahmad Syuhada, represented general knowledge, were given the doctorandus title to their name. The combination of general knowledge and Islamic theology was a new trend, if not a breakthrough in Indonesian 
higher education. The history of Indonesian Islamic universities was arguably rooted in Syuhada. The earliest Islamic university in Indonesia (which bear the name 'university', thus resembled to university in the sense of Western university) was UII, which had four faculties (Law, Religious Studies, Education and Economics). It is important to note that in its formative years, Ull seriously lacked of campus facilities. They often used rooms located on the lower grounds of the Syuhada Mosque for teaching and studying. Moreover, muslim youngsters who enrolled in UNRA PTMS originated from Yogyakarta and outside, such as East Java. Within two years, UNRA PTMS attracted so many people that the study room was no longer enough. Indeed, those who wanted to attend the college, could only do it by standing at the back of the room. (Suratmin, 200I: 57). Subsequently, Syuhada's increasing role in Islamic higher education, especially with regards to UII and UNRA PTMS, gave Islamic leaders the reason to eastablish state-operated Islamic higher education institutions that are now known as IAIN (Suratmin, 200I: 57; Asari, 200I, 235).

\section{REACTING TO CHRISTIANIZATION}

The relationship between the adherents of Islam and Christianity in Indonesia can be traced back to the coming of Europeans, who came here to trade, but also brought missionnaries to evangelize the native population. This relationship was primarily reduced to the issue of religious conversion, or to be exact, Christianization. Catholics (missie in Dutch) and Protestants (zending in Dutch) were known to be very active in proselytizing to the native population, both to those who already embraced a world religion like Islam or ethnic groups in remote areas who still practiced animism and politheism.

Around the late ig6os, the issue of Christianization causing the relationship between Muslims and Christians to deteriorate (Azra, 2002: 320). In 1967, a Christian leader was viewed harassing Prophet Muhammad. As a result, a church was burned down. In Aceh, Muslims challenged the establishment and the use of a new church in an area which had no Christian inhabitants. The most important concern of Indonesian Muslim leaders was the expansive and aggresive efforts of the evangelists (Azra, 2002, 320).

This was the background to one important event in Kali Code, a native kampung next to Kotabaru and very close to Syuhada Mosque. In the beginning of the I970s, Kotabaru was arguably a slum area of Yogyakarta. Many of the inhabitans worked as trishaw drivers, porters, small mechanics, and scavengers. These were 'clean' jobs. Many others were pickpockets and drunkards. Impressions that one gets when talking about Kali Code from that time are of a dirty, chaotic, vile, and crime ridden place (Pour, I995, II5-II6). A Catholic architect, Y.B. Mangunwijaya, widely kown as Romo Mangun, came and changed the face of Kali Code. Inappropriate houses which did not meet health standards were removed and rebuilt. Indirectly this and other related actions improved the Kali Code inhabitants' economic state.

Despite his success, the issue of Christianization emerged. His background as an ecclesiastic graduating from College for Philosophy and Theology (Perguruan Tinggi Filsafat dan Theologia) St. Pauli, Yogyakarta, made his true intention questionable. He did not establish any church, but Muslims saw a massive conversion among inhabitants of Kali Code. The numbers of Muslims decreased while the numbers of Christians sharply increased.

A question arose among Yogyakarta Muslims: why did Syuhada Mosque fail to take care of the inhabitants of Kali Code, which in terms of both religion and geography were far closer to the mosque than any other religious community? One of the pretexts was that Kali Code was not among on the top priority of Syuhada's dakwah (proselytizing) movement; Syuhada's dakwah, as mentioned previously, mostly focused on attracting well-to-do inhanbitants of Kotabaru as well as educated and established groups in Yogyakarta.

Yet, under the criticism of the Syuhada's ignorance to Kali Code, Syuhada's management and community began to address the issue. Information about the rapid conversion of Kali 
Code was the catalyst for Syuhada to give more attention to Kali Code. Syuhada management decided to inspect directly what was happening in Kali Code. After the issue was confirmed, they took measures to counter this Christianization (Masyhuri, personal communication, January I2, 2007). A youth named Hasnawi Harahap was tasked by Syuhada management to deal with Christianization in Kali Code. His mission was to defend the aqidah (creed) of Muslims living in Kali Code. Afterwards, he and other Islamic teachers from Syuhada frequently held Koran recital groups there.

It was also reported that a hall owned by a Neighborhood Association (Rukun Tetangga, RT) in Kali Code was frequently used for religious services (kebaktian) (Masyhuri, personal communication, January I2, 2007). A cross was seen hanging on the wall. An Islamic teacher from Syuhada was surprised once he saw it. He then held a meeting with members of the Syuhada community, a meeting which decided to improve the quality and quantity of Islamic activities in Kali Code. With persuasive efforts, the cross was finally removed by the inhabitants of Kali Code, and the RT hall was re-used as a center for Islamic activities there.

In addition to Kali Code, Syuhada's attention to the Christianization issue was also found in Gunung Kidul, where Christian missionaries were also active. There, Syuhada had a desa binaan (village under care) which was handled by activists from Corps Dakwah Masjid Syuhada (CDMS), a youth wing of Syuhada. Besides, some Islamic teachers from the PAMS often came to the elementary schools to counter Christianization. Students from the Institute of Islamic Studies of Syuhada Mosque (Sekolah Tinggi Agama Islam Masjid Syuhada, STAIMS) were also especially energetic in responding to this matter.

The issue of Christianization in Kali Code, and also in some places of Gunung Kidul, both poor areas of Yogyakarta, became a national polemic. Many criticized the Christian evangelists, but some others demanded Muslims to perform self-introspection in order to find out why this happened (Taha [ed.], I997, I27-I28).

\section{NEW ORDER AND THE RISE OF MUSLIM YOUTH}

In the I980s, after several decades building an image of a modern, middle class mosque that played a significant role in the development of Muslims life in Yogyakarta, the Syuhada Mosque attracted a new group of members who energetically participated in its activities: students from secular campuses all over the city, but primarily from UGM. The most well known university in the city, UGM, was located only a few kilometres from the mosque. Before we go deeper to understand the students' role at Syuhada, it is necessary to understand the situation of Indonesia's campus life around that time. Since the I970s, a new school of thought in Islamic studies appeared and was constantly endorsed by such figures as Djohan Effendi, Nurcholish Madjid, Ahmad Wahib and Abdurahman Wahid (Barton, I999, 515). They introduced a novel approach to Islamic thought, namely Neo-Modernism, which emphasized a committment to pluralism and democratic values.

In response to that liberal thinking, as well as an endorsement of the Islamic Revolution in Iran, discussions centering on Islamic revivalism were blossoming on many secular campuses in Indonesia, especially between the mid-I980s and the beginning of the I990s. One important Islamic leader who initiated the proliferation of Islamic teaching on secular campuses was Mohammad Natsir, a notable leader from the Masyumi Party and former Indonesian prime minister. In order to enhance Islamic activities on campus, he proposed the establishment of mosques in universities and dormitories for students who would then become the active agents of change. A number of campus mosques were established in the I97os. Islamic activities soon emerged on campuses in such cities as Jakarta, Bandung, Bogor and Yogyakarta. The most active mosque community was at Salman Mosque at the Bandung Institute Technology (Institut Teknologi Bandung, ITTB) in Bandung, which strongly influenced Islamic activists on other campuses, including in Yogyakarta.

At UGM, there was a mushrooming of student discussion groups concentrating on Islamic matters and often started with an 
informal course on the interpretation of the Koran, taught by UGM lecturers. This course was very popular among students, and it was attended by both UGM and non-UGM students (Juliantara, I995, 223).

Meanwhile, a number of UGM students stayed in Syuhada's student dormitory and were very keen on participating in Syuhada-held events. Subsequently, these students played an important role in applying the models of Syuhada's Islamic activities into the Muslim students' association at their campus, the Shalahuddin group of UGM. For instance, discussions about the contextualization of Islam in the modern world and in an Indonesian nation-state conducted by Shalahuddin was strongly influenced by Effectice Study of Islam (Study Islam Efektif, SIE), a course on Islam held by Syuhada since the beginning of the I980s. This SIE was a specific discussion forum made up of 20 people, mostly UGM students. For several months, the members were given lectures on the main Islamic principles, such as the oneness of God and proper behavior in Islam. More importantly, this discussion group also talked about current political matters, thus stimulating the students to feel responsible for the declining position of Muslims in the New Order regime. This combination of religious and political teaching appeared to encourage UGM students who followed the course to implement it during the formative years of Shalahuddin group.

The birth and rise of Shalahuddin did not put an end to the SIE. They both helped each other, informing one another if one of them invited famous speakers from Jakarta, for example from the Indonesian Association of Muslim Intellectuals (Ikatan Cendekiawan Muslim se-Indonesia, ICMI) (R. Lubis, personal communication, February 2I, 2007).

As previously stated, the Salman group of ITB was essential in the development of Islamic activities on Java's main campuses. According to Rahmat (2008: 29), before the Salman community's influence came to Yogyakarta, there were already three dakwah movements in Yogyakarta: the Mardhiyyah group (State Institute of Teacher Training, IKIP Yogyakarta), the Syuhada Mosque group and the Salahuddin community (UGM). These three groups were supported by students from various state and private universities in Yogyakarta, reflecting their wide basis of supporters.

At the height of the New Order regime, Syuhada and its intellectual and religious network took part in the criticism against the regime, although not as overtly and sharply as other mosques, especially the Salman Mosque in Bandung. After the peak of student political activism in the mid-I96os, student political activities in I970s sharply declined because of the New Order's suppression of such movements. Intra-campus organizations were banned through the infamous Normalization of Campus Life (Normalisasi Kehidupan Kampus, NKK) in I978. But, Islamic activists continued to struggle, and they thrived. Networks of Islamic activists in Java's major campuses brought an Islamic activist named M. Imaduddin Abdulrahim to Syuhada. Also known as Bang Imad, he was a Muslim activist well known for his efforts in the Islamization of Indonesian secular campuses through his role in founding the Salman Mosque at ITB and his subsequent role spreading stricter Islamic principles through Java's main universities. Once he delivered a sermon at Syuhada. He believed he was under surveillance by a government intelligence agent who lived close to the mosque. During his speech, he noticed the surveillance, openly revealed the name of the agent and asked him to write down his speech about Muslim revival. This story was spread among Muslim activists as an effort to ensure that Bang Imad-and undoubtedly also Syuhada Mosque-was a strong symbol for Muslim activists fighting against the New Order's repression of Muslims (Asshidiqqie [ed], 2002: 20I).

Nevertheless, despite the above mentioned story of anti-regime resistance, as far as available sources are concerned, Syuhada Mosque generally remained passive, in a political sense, towards several political changes at a national level that affected Muslim organizations during the I970s and I980s. These changes included the fusion of Islamic parties in 1973 and the application of Pancasila (five principles) as the so-called asas tunggal (sole basis) of any organization in the I980s. In other words, 
these two changes had no substantial impact on Syuhada. The fusion primarily had an damaging effect to Indonesian Muslims' political channels, especially the Islamic party PPP, whereas questions about asas tunggal were mostly debated among national-level sociopolitical Islamic organizations such as Muhammadiyah and NU (see for instance Assyaukanie, 2009) rather than socioeducational institiutions like Syuhada. Another explanation for this comes from internal sources. One of Syuhada's most influential activists, Habib Chirzin, stressed that unlike other mosques, such as the Salman Mosque in Bandung, which was very critical to the New Order regime, Syuhada Mosque was in fact a 'government's mosque', given the fact that its opening ceremony was attended by numerous local and national government officials and its leadership was managed by representatives of the Yogyakarta Sultanate. Therefore, instead of paying much attention to politics, Syuhada focussed heavily on improving the spirituality, culture and social welfare of the Muslim community in Yogyakarta. In Chirzin's words, Syuhada launched 'social and cultural resistance' instead of 'political resistance'. As a consequence, the Syuhada Mosque managed to avoid the cruel treatment of the New Order regime, although in some instances the public activities of social activists associated with Syuhada were surreptitiously supervised by the New Order apparatus (Sopyan, 20I4: 68-73).

\section{CONCLUSION}

Established in the early I950s, Syuhada Mosque was more than a simple mosque. Despite its main function as a place for worship, it was to a large extent also an historical monument built to commemorate Indonesia's victory against Dutch colonialism and Japanese Occupation. This was indicated by the name of the mosque, the location where it was built, the variety of sociopolitical backgrounds of its founders and numerous other symbols associated with it. This study traces the history of Syuhada not just from the day its first stone was laid, but from the origins of the the area where it was built, Kotabaru, from the late igth century to the peak of the mosque's activities in the ig8os. This shows that, from an historical point of view, Kotabaru was a contested area during different regimes and after being dominated by two foreign powers it was eventually taken over by Indonesians, which is commemorated by the establishment of the mosque.

This study finds that the Syuhada Mosque did not just play a role in enhancing an individual's devotion to God, but was also a center of social, even political discourses at a city and national level. This finding is consistent with studies of the social and educational functions of a mosque in Muslim society, in which the role played by the mosque management and the active participation of the mosque's community are essential in widening the functions of the mosque (Imamuddin, I984; Prasetya, 2014).

In its formative years, Syuhada faced a difficult problem. It was not built within a kampung where the inhabitants were naturally embedded to the mosque, Syuhada had to creatively attract people's attention and involvement. Syuhada management did many things to attract people from both the Kotabaru area and beyond. As such, Syuhada was designated to be ideologically open, socially sensitive, technologically responsive and politically active. Even though Syuhada was inclined to Muhammadiyah, there were no striking problems concerning disputed matters in Islamic teaching. It allowed Muslim communities from different groups and schools of thought, and every dispute about differences among Muslims seemed to be deliberately put aside. Its social functions, however, rapidly changed over time. While in the beginning its main community were those Muslims living in the Kotabaru area, it later had to expand its scope because of declining support from this immediate neighborhood. Thus, Syuhada management constructed diverse agendas to attract a new community beyond Kotabaru, namely educated and well-to-do Muslims of the city of Yogyakarta. But this was challenged by criticism of Syuhada's failure in maintaining the Islamic identity of its close neighborhood in Kali Code, a criticism which was soon rectified by Syuhada's dedication to the Kali Code.

During the four decades of its presence, the activities of management and the community of Syuhada represented efforts to draw the involvement of Yogyakarta's middle class Muslims into events held by the mosque. This study includes several cases of modern approachs to proselytiz- 
ing Islam used by Syuhada, such as the founding of the up-to-date education systems (TK and university) and the constant use of radio. In the I950s, the core membership of the Syuhada community encompassed government officials living in Kotabaru, while in I970s and I980s it was comprised of university lecturers, doctors and other professionals. University students were also essential in forming the Syuhada community, especially in the ig6os during the anti-communist struggle and in the I980s when they started student-based Koran recital groups, which were subsequently opposed by the New Order for fear of its ideological nuance and militancy. If we see the development of Syuhada from the I950s to the I980s, even until recently, that reputation as a bastion of modern and intellectual Islam, not just for Yogyakarta but also for Indonesia, remains intact.

\section{REFERENCES}

\section{Books}

Al-Asad, Mohammad. (I992). The Mosque of Muhammad 'Ali in Cairo. Muqarnas, Vol. 9 pp. 39-55

Al-Asad, Mohammad. (I999). The Mosque of the Turkish Grand National Assembly in Ankara: Breaking with Tradition. Muqarnas, Vol. I6 pp. 155 -I68

Asshiddiqie, Jimly, et al. (eds.). (2002). Bang 'Imad: Pemikiran dan Gerakan Dakwahnya. Jakarta: Gema Insani Pers.

Assyaukanie, Luthfi. (2009). Islam and the Secular State in Indonesia. Singapore: ISEAS.

As, Imdat. (2006). The Digital Mosque: A New Paradigm in Mosque Design'. Journal of Architectural Education (1984-), Vol. 6o, No. I, pp. 54-66

Azra, Azyumardi. (2002). Historiografi Islam Kontemporer: Wacana, Aktualitas, dan Aktor Sejarah. Jakarta: Gramedia Pustaka Utama.

Barton, Greg. (1999). Gagasan Islam Liberal di Indonesia: Pemikiran Neo-Modernisme Nurcholish Madjid, Djohan Effendi, Ahmad Wahib dan Abdurrahman Wahid I968-I980. Jakarta: Paramadina.

Bruce, Allan. (1996). Notes on Early Mosques of the Malaysian Peninsula. Journal of the Malaysian Branch of the Royal Asiatic Society, Vol. 69, No. 2 (27I) pp. 7I-8I.

Creswell, K.A.C. (I934). The Great Mosque of Al-Mansur of Baghdad. Iraq, Vol. I, No. I pp. IO5-III
De Graaf, H.J. (I963). The Origin of the Javanese Mosque. Journal of Southeast Asian History, Vol. 4, No. I pp. I-5.

Departemen Pendidikan Nasional. (200o). Keterlibatan Ulama di DIY pada Masa Perang Kemerdekaan I945-I949. Jakarta: Departemen Pendidikan Nasional.

Erlangga (no year). Mesjid-mesjid Bersejarah di Jakarta. Jakarta: Erlangga.

Harnoko, Darto, et. al. (2003). Demokrasi dalam Perjalanan Sejarah: Studi Kasus di Daerah Istimewa Yogyakarta 1945-Awal Reformasi. Yogyakarta: Balai Kajian Sejarah dan Nilai Tradisional Yogyakarta.

Husnil, Muhammad. (20I4). Melunasi Janji Kemerdekaan: Biografi Anies Rasyid Baswedan. Jakarta: Zaman.

Imamuddin, S.M. (I984). Mosque as a Center of Education in the Early Midde Ages. Islamic Studies, Vol. 23, No. 3 pp. I59-I70

King, Geoffrey. 1978. Traditional Najdi Mosques. Bulletin of the School of Oriental and African Studies, University of London, Vol. 4I, No. 3 pp. 464-498

Kuntowijoyo. (I994). Dinamika Sejarah Umat Islam. Yogyakarta: Shalahuddin Press dan Pustaka Pelajar.

Kusno, Abidin. (2003). The Reality of One-Whichis-Two: Mosque Battles and Other Stories: Notes on Architecture, Religion, and Politics in the Javanese World. Journal of Architectural Design, Vol. 57, No. I pp. 57-67.

Latif, Yudi. (2012). Inteligensia Muslim dan Kuasa: Genealogi Inteligensia Muslim Indonesia Abad ke-2o. Jakarta: Democracy Project (digital edition).

Nguyen, Ann W. et. al. (2013) Mosque-Based Emotional Support Among Young Muslim Americans. Survey of Religious Research, Vol. 55, No. 4 pp. 535-555.

Noer, Deliar. (I973). The Modernist Muslim Movement in Indonesia, 1900-1942. Singapore: Oxford University Press.

Panitia Pendirian Masdjid Peringatan Sjuhada. (I952). Kenangzan 'Masdjid Sjuhada'. Yogyakarta: Panitia Pendirian Masdjid Peringatan Sjuhada.

Parihar, Subhash. (2004). Historical Mosques of Sirhind. Islamic Studies, Vol. 43, pp. 48I-5Io.

Pour, Julius. (I995). Pengalaman dan Kesaksian Sejak Proklamasi sampai Orde Baru. Jakarta: Grasindo.

Rahmat, M. Imdadun. (2005). Arus Baru Islam Radikal: Transmisi Revivalisme Islam Timur Tengah ke Indonesia. Jakarta: Erlangga.

Rahmat, M. Imdadun. (2008). Ideologi Politik PKS: Dari Masjid Kampus ke Gedung Parlemen. Yogyakarta: LKiS. 
Rosen-Ayalon, Myriam. (2006), The White Mosque of Ramla: Retracing Its History. Israel Exploration Journal, Vol. 56, No. I pp. 67-83.

Strassler, Karen. (2010). Refracted Visions: Popular Photography and National Modernity in Java. Durham and London: Durham University Press.

Supardi dan Teuku Amiruddin. (200I). Manajemen Masjid dalam Pembangunan Masyarakat: $\mathrm{Op}$ timalisasi Peran dan Fungsi Masjid. Yogyakarta: UII Press.

Suratmin. (200I). Mengenal Selintas Masjid Syuhada Yogyakarta. Yogyakarta: Masyarakat Sejarawan Indonesia Cabang Yogyakarta.

Suwarno, P. J. (1994). Hamengku Buwono IX dan Sistem Birokrasi Pemerintahan Yogyakarta I942-I974: Sebuah Tinjauan Historis. Yogyakarta: Kanisius.

Taha, Idris (ed.). (I997). Dakwah dan Politik 'Da'i Berjuta Umat' K. H. Zainuddin M.Z. Bandung: Mizan.

Tanter, Richard and Kenneth Young (eds). (I993). Politik Kelas Menengah Indonesia. Jakarta: $\mathrm{LP}_{3} \mathrm{ES}$.

Universitas Atma Jaya Yogyakarta. (I990). Sejarah Universitas Atma Jaya Yogyakarta. Yogyakarta: Universitas Atma Jaya Yogyakarta.

Yani, Ahmad. (I999). Panduan Memakmurkan Masjid: Kajian Praktis Bagi Aktivis Masjid. Jakarta: DEA PRESS bekerjasama dengan Lembaga Pengkajian dan Pengembangan Da'wah Khairu Ummah.

Yetkin, Suut Kemal. (I959). The Evolution of Architectural Form in Turkish Mosques (I300-I700). Studia Islamica, No. II pp. 73-9I

\section{Thesis}

Hudianto, R. Reza. 'Perkembangan Pemukiman Masyarakat Eropa di Kota Yogyakarta (I9I7I936)', unpublished undergraduate thesis, Gadjah Mada University (UGM), I997.

Sopyan, Imam. 'Dari Dakwah Normatif ke Dakwah Transformatif: Dinamika Kaum Muda Masjid Syuhada Yogyakarta, I954-I980-an', unpublished undergraduate thesis, Islamic State University (UIN) Sunan Kalijaga Yogyakarta, 2014.

Pamungkas, Dharmawati Dewi, 'Seni Rupa Islam pada Gaya Arsitektur dan Interior Masjid Agung Yogyakarta awal Abad XX', unpublished thesis, Gadjah Mada University, I996.

Prasetya, Andri. 'Optimalisasi Fungsi Masjid sebagai Ruang Publik: Studi tentang Peran Pengelola dan Transformasi Ruang Publik di Masjid Jogokariyan', unpublished undergraduate thesis, Gadjah Mada University, 2014.

\section{Proceedings}

Farabi Fakih. (2005). Benteng Kotabaru: Antara Ada dan Tiada di Jaman Poskolonial. In Proceedings of the seminar Street Images: Decolonialization and Changing Symbolism of Indonesian Urban Culture between I930s and early i96os. Yogyakarta: Center for Southeast Asian Social Studies, Gadjah Mada University.

Asti Kurniawati \& Dwi Ratna Nurhajarini. (2005). Yogyakarta dalam Persimpangan 'Tiga Wajah' (Reproduksi Simbol di Ibukota Republik Indonesia). In Proceedings of the seminar Street Images: Decolonialization and Changing Symbolism of Indonesian Urban Culture between I930s and early i960s. Yogyakarta: Center for Southeast Asian Social Studies, Gadjah Mada University.

\section{Online source}

Yunanto Wiji Utomo, 'Kotabaru, Jelajah ke Kota Taman Tua', dalam http://www.yogyes.com/ id/yogyakarta-tourism-object/places-ofinterest/kotabaru/, [accessed Aug 3, 2007].

\section{Brochure}

Informasi tentang Sejarah Taman Kanak-kanak Masjid Syuhada. (no date). No city: no publisher. 